\title{
A Past: Wintered like a Circus
}

\section{Frank Stanford}

The house had twenty-two rooms. There was a mirror, a blue bottle of dark wine, a painting by the one they call Chagall, and a large fern in most of the rooms. Not much furniture: unfinished wicker pieces, orange crates, and a chiffonier containing dead chrysanthemums, verbena, and old correspondence. The ceilings were high enough that the woman could lean her cane poles against the wall when she returned from fishing.

At a quarter past four, every morning, the crow, whose tongue she split years ago, lit on the balcony outside her bedroom window. It looked like a pirate, strutting the deck of its ship, as it walked to and fro on the railing.

The woman always slept with the canopy down and the French doors open, no matter what the weather. The draft caused the smoke from the fireplace to drift out of the upper room, as if it were a hidden lake losing its morning fog.

There was some fog in the fields, anyway.

"J'ai tant rêvé de toi que tu perds ta realité." The crow did not speak English.

The woman was thirty years old but did not look it. Her hair was black; not the shade of the crow. The bird was so black, it looked blue. She had a few strands of gray, the color of the tuft under a fox's neck. It is that way in the forest, sometimes. You see red leaves in July. She thought she had Just enough for a small craft to crack-up on.

She left some sparkle by the window one summer. A wind came up. It went through the house, and then, out again, all about the premises, the moonlight picking it up. Someone passing by in a wagon thought the lady was throwing away her jewels. Some of the sparkle caught in the gables, next to the wasp nests. On a quiet night, you could hear the insects from the road.

The long green buds of the ash trees sifted through the bedroom windows. They never fool the birds, but often the fish have them in their bellies when you slit them open. A Staffordshire bowl, half-emptied of almonds, was on the mantle. Above it was an oval mirror, a mounted alligator, and the painting: The Bark. 
The boy was so beautiful: "It was a sin." She had put the many mirrors up, not so he could look at himself, but so she could watch him look into them. She dreamed there were deep blue ponds in every room. Each mirror was like a stranger, returning now and then like one who had been banished. She recognized each exile. Most of the mirrors were hung at a high, inclined angle, so one was always looking up at them.

A few miles down the road, at that same time of dawn, another woman was looking from her kitchen window, glad she got out of bed early, did the children's chores for them so they could sleep late until the schoolbus. Her husband, who had his feet propped up on the table, told her about money and how lucky they were. He'll be going to his job soon, she thought, trying to recall her dream, a way she passed the time each morning.

She wouldn't have had the same dream, had she not seen Paradise in their stable. She looked down at the muddy newspapers on the floor. Her husband was not a sharecropper like most of the people who lived on the road, which meant their house was a little better than the other shacks. He was a rough carpenter who could do a little wiring in a pinch. Their house was kept-up well on the outside-a fairly new coat of paint which had gone through a season quite well, no junk in the yard, but the inside was not tidy at all. In this way, it was just the opposite of the sharecroppers' homes. Often enough, her husband had lectured her: "Those folks up the road, them and the niggers, they do whatever they please, paying nobody's mind, and we have to suffer the consequences; they get away with murder." Still, she envied them, and not their way of life. She hadn't learned to "resent" it yet, like him. He was always telling her how much he "resented" things.

She smiled at herself in the window pane. All her life, even when she was a child, everyone had told her: "Kelly Buck, you have beautiful teeth." Now, thirteen years from when she was getting splinters in her feet from dancing on the gym floor, the free dentist at the County Health Center had told her about how she had "a rare gum disease, common among women your age in similar situations." He looked at her legs, hesitating, when he said "similar." The only thing she could think to say, when he told her: "Those teeth will have to be removed," was "How much money do you get?"

The boy was walking down the road, the crow on his shoulder. He swung a pail. In it were mushrooms and a few stray berries. He wiped a spider from his eye, and the bird spread its wings. It was a spring morning, or going to be. Earlier, a shower had come and gone. It might even turn out to be a bright day, but a few heavy, gray clouds were still looming. They were getting darker, he thought, like the sacks you put leaves in. He shut his eyes, without breaking his stride, and tried to make out the odor of the sky, still dark.

She was waiting for honey to come from a jar onto a biscuit, when she first noticed him. It would be good to forget about her teeth, and remember the dream. 
"I have many mouths to feed, and you're pouring good honey on the floor," her husband said. "Is it the time of morning, or the boy?"

"I believe it is both," she said. "This is the third morning in a row he hasn't come for the bread. He just passes by."

"They pay the days they don't get it; it don't matter to us. You know how they both are, anyway."

"It matters to me," she said, not looking at him, before he had a chance to finish whatever it was he was saying.

"Why should it? He's a mooncalf, I don't care how he looks. So what; the preacher has a nice looking daughter, but she's deaf and dumb. She makes that drooling sound. She's pretty, but she's not right. Take Cary Grant for instance, in the movie we saw last evening on TV. What was the name of it?"

"Only Angels Have Wings."

"You know how they claim he is."

"The boy isn't a mooncalf, he's just strange. He's not cruel, either; he's not crazy, I don't care what any of you say. I don't think he's that kind of way."

"If it weren't for her, he'd be in Whitfield; and don't you think he wouldn't."

"For him to be there, in a place like that, is like ..."

"Be quiet, he's coming. Run put some more clothes on."

"If I knew the boy was there, I'd-I'd take the youngest and leave here. I really would."

"I resent that."

The boy was dripping wet. He hadn't bothered to put on a shirt, only the yellow raincoat. Kneeling down outside, unlacing the broken fishing cord from his shoe, he waited for her to open the screen door so he could hand her the dime. He knew there was no need to knock. His hair was like a clump of grass that grows underwater. His eyelashes were like a painter's brushes. His shoes were so wet, most would not notice the scuffs.

The woman looked away when the boy removed his shoe, then she unlatched the screen. A little breeze brought in the heat of his foot. She smelled it with the soaked leather.

"You better get some polish on your hide before you ruin those shoes," the husband said, tying his boots, laced very tight, as he appeared about ready to leave for work.

"I use saddle soap," the boy answered him, taking the warm loaf of brown bread from the woman. His eye went toward the basket, "I've forgotten a cloth again."

"I have something to wrap it in," she said.

"Better pour that fruit into the basket, boy; you don't want it to spoil. Your pail is probably full of rainwater."

The woman could not find a clean towel, and the last paper sack had gone for her husband's lunch. She reached up in her hair, drawing out a few pins, and undid her blue scarf. The man looked at her as she took down her hair in front of the boy. With pins in her lips, and her thin arms raised above her 
shoulders so her breasts shone full through the silk shift, she spoke to the boy in a way that was almost challenging, "And how is Miss Grainger?"

"She went riding."

The husband waited for his wife to hurry, waited for the boy to go, so he could leave.

Some men will always suspect, laying themselves open; whereas some women will confound simple things with an indefatigable serenity, and make themselves more mysterious. Some men will let even the moon get in their craw, while some of these women will follow its tracks like an animal too beautiful to kill.

The two of them looked at him crouched on the floor, his arms wrapped around his shoulders.

These men, those who think of arrows and not birds when they see feathers, one of whom was the husband, will always lack a certain knowledge of things because of this suspicion which they carry over their backs like a carcass. These women, however, and this wife in particular, share none of the ribs whittled into knives. Because this woman often takes strolls, alone, under the quartermoon, she has known for some time-simply by the way the boy folds his arms and shivers when, inside, he can no longer feel the sun on his body, knowing there is none this time of morning and still might not be any later in the day-the two of them sleep together.

"J'ai tant rêvé de toi qu'il n'est plus temps sans doute que je m'éveille," said the crow, waiting outside the screen, like a friend in a hurry to leave.

The boy reached in his eye after some sleep. "I'm sorry, but I used your rags."

"What did you do, sop up somebody's blood, somebody you got rid of," the man said with a sardonic smile, breathing in, short of wind as he talked.

He answered the man, looking the woman in the eyes, as if he knew she would know, "I tied the rags together and made a tail for the kite," thinking $I$ soaked them in water and Regular gasoline. The kite was a Chinese dragon. It was way over on the other side of the river where no one could see it. I lit the string and let go of it. It was waxed, the kind you tie to two Pet Milk cans and talk secrets to one another. I lit the string and let go of it. There was a lot of humidity. The dragon burned like the last dance at midnight. There must have been a tornado that day, it was so dark. The sky, it was so dark, like a blueberry. The fire stayed on the string. Shooting star. Everything dissolved. Way up there, dissolved just when you bat your eyelids. And the dragon blew up. Glory be.

"Jamais plus ils ne se revirent." The black bird could throw his voice like a ventriloquist.

"Did you? I remember the kite. You were out in a field, lying down, your legs crossed. It hadn't rained in some time. You were popping berries in your mouth, shading your eye with your hand-you had suede gloves on, I wondered why; you were looking up at the kite. The sun looked like the moon; you know how it filters through the clouds. I didn't understand the way your horse was behaving, until I saw how you'd tied the string to the pommel. He was grazing, pawing the weeds near the pond. I remember." 
The boy put his finger to his lips, pointed outside where the crow was, and whispered, "Say something, else it'll get its feelings hurt."

The man smirked, but his wife said, "And the crow looked like a count's falcon!"

Too excited to be surprised that she, too, saw things his way, he let his moody voice wander in interest, "Do you remember the brushfire?"

"Yes!"

The man remembered it, too. The boy had not stopped to help lend a hand and put it out. There was something suspicious about a fire starting that time of year in that kind of weather. To make things worse, he had ridden through the brushfire, disappearing in the smoke, then ridden out again, leaping over a flaming fence, only to enter again, taking things they could not see. Finally, he rode away backwards, laughing at the men as they busied themselves with old blankets, buckets, and shovels.

The woman was taking the dime he'd given her from her apron, then putting it back again, trying to make it roll out in her palm like dough. She did this so many times, the tips of her fingers were numb. Intently, the boy kept his eye on this procedure. He knew what it felt like When I try to button my jeans in the wintertime, when they're too tight, right after a wash. It hardly made a sound when it dropped from her hands onto the dirty floor, rolling until it slipped into a space between the boards. If there had been any sun, it would have hit it just right, picking it up like a piece of broken glass.

The woman's husband got up, went over to the spot where the coin lodged itself, and tried to retrieve it with his fingernails. He was thinking butterfingers out loud, while the boy thought about his bird swallowing the prism. She pondered the first time she had ever seen him He tied a new rope to an Underwood typewriter and threw it in the river. He was juggling oranges. She told Miss Grainger what she saw. She said, "He's like that; he was writing a letter; a ladybug flew in the window and lit on the paper. He hit the numeral 0 , or maybe it was the letter $o$, just as it hit the paper. 'Fate' he said to me in a faraway voice. It upset him. He drank a bottle of white lightning and stayed in a tree for two days. The whole while he was up there the only words he said were, 'Bring me my clarinet. Did you see me kill her? A real musician would have had more control with his fingers. More control, I say, you hear. I think I did it on purpose. The little red lines were like crosshairs. Over The Hills And Faraway.' For weeks after that he would come into my room, telling me there were leeches on him, asking me to burn them off. Like a gentleman, he kept asking me if I needed a light." It was the first time Miss Grainger ever said more than $\mathrm{Hi}$ or Bye to her, and she only took time to speak this particular time because she was drunk again, and then she lied because she wanted to impress upon "the other woman" that the boy slept by himself in his own room. No matter how Miss Grainger tried to explain things, she knew better.

Another cloud passed over the invisible sun, and the boy, who was shivering from the cold, stomped down his feet, flicked his forefinger across the ridged edge of the dime, unwedging it. "The lady on it looks like an angel, doesn't she?" 
He handed it to the man. He gave it to his wife, and she put it in a brown jar. The dark bread was ready on the table. It was wrapped in her blue scarf. She pinned back her hair. "It's clean," she said.

"I know it is," the boy said, leaving with the loaf.

"You'll get cold," she said. "You'll catch your death."

"I'm already cold," he told her with something you might call a smile.

"And what do you want me to call you the next time I see you?"

Looking at the pearl on the end of her hair pin, he thought about the volcano he had dreamed the night before. He thought Lava, but he cleared his nostrils and said, "Oyster."

"It's done then."

He left with the fresh loaf and the bird.

"The longest he's stayed."

"How would I know," the husband said.

"He's beautiful."

"He's a lunatic."

"Sometimes he's in my dreams-when I can remember them. I never told you before. I wake up in the dark of the morning to get you and the children off, before any of you are thinking about waking up, and I move around the house as if I was still asleep. When I dream of him, it is nearly a dew. Yes, a dew. And it takes ever so long to dry. Like the dew was moonshine, and I had a hangover. I'm standing in the back of the gym, because nobody will ask me to dance. He comes up behind me, lisps in my ear, and I feel like I was floating in the pond out yonder; eelgrass tickling the bottoms of my feet. He's older in the dream. He looks like the man in that shirt ad, with premature gray. Isn't that something, honey?"

The man payed no attention to her, as she went on about the boy, leaning against the window. Instead, he was crushing ants, one by one, as they walked across the table with the sugar like Pharaoh's slaves. He was crushing them with his ring, his high school class ring he hadn't taken off for thirteen years. He went through the motions like a bishop affixing a seal.

"Honey? Last night I had three dreams."

"I think I'll start swimming again. I bet I could swim crost the river after a month or two of practice. I'm going to see what the boys at work think about it."

Like a medium without a wooden table to lay her hands on, she looked out into the dark and quiet fire of daybreak, "He was crouched down in the barn loft, beating his fist into the catcher's mitt, looking at the moon. Maybe it was a palette; he had one of those caps on. He told me, not taking his eye off the moon, 'She spit on it, but it won't get by me.' Then he was out back on the porch, just in the yellow of the buglight, cleaning fish. The scales would fly up and sparkle. He had on his underwear. A cat walked past a clump of purple clover. It was going towards him. He slit the belly and the guts spilled into a pie pan. There was a bucket of sand next to him. You know, like a person takes with them when they want to mix concrete. My eyes felt like he was sprinkling sand in them. Maybe it was a draft on the ceiling. I was on the porch. He saw 
me. I had a can of soured Pet Milk I was going to give the cat. I walked out towards him, on the path to the outhouse so my feet wouldn't get evening wet. I stooped over with the milk, but the cat ate the fish entrails. The boy took hold of the milk. He drank it like he was thirsty. He said, 'Here you go, Here you go. Come babe, Come babe,' beating his fist into the mitt. It was heinous and entrancing. The scales dried up all over his skin. I heard him scaling fish all night long-saw the shadows; even felt him down at the foot of the bed, like a dog scratching himself. It was a dream, honey. Then I heard him out at the pump. ' $O$, the water,' is what he said. He drew a circle in the mud, and I thought I heard him say, 'I dare you, $O$ the water.' The fish eggs were the same color as the porch light."

Still at the window, she stopped, waited for a rabbit to get out of the middle of the road. Suddenly, she turned to her husband, knowing he wasn't paying her any mind, and asked him, "You want to hear what else?"

"I got to go to work. We had a lot of rain the last few days. I got to get something done. I don't need you spoiling my mornings, telling me what you dreamed about some lunatic. He's a mooncalf, I tell you. Ask anyone. Why he changes his name fifty-two times a year. Give me another shot of coffee."

The boy loped home, trying to make his legs longer than they were. The sun was drying his hair, and sweat was breaking out on his forehead like a fever. It was still very early.

The woman took the guinea speckled pot off the stove with her apron bound around her hand, and listened to what her husband told her, "Sweep this place out while I'm gone. Put some Pine-Sol down. While you was having those nightmares, I was having muscle cramps."

"Let me tell you another one, please, You got time with your coffee. Please listen. I dreamed I came home one evening and you and the children were gone. The car was here, but you all weren't. The ballerina on Sister's jewel box was turning around. You took the dogs, too. Even the black and tan. I ran out and got in the car. The gas tank was on empty, but I thought the faster I went, the longer it would last. I drove fifty miles an hour all the way to the crossroads. When I turned onto gravel, I drove sixty. If I had made it to the macadam. surely I'd pushed ninety or better. You listening? The night was blacker than the Buick. I hit a rut, and one of the hubcaps came off. The thought of it spinning through the weeds, like a wounded cottontail, made me think of the boy. Before I ever knew it, I went across the bridge, and I knew that the dirt dauber nests in the two-by-fours turned to dust. You know what I thought in the dream?"

The man slurped his coffee, scorching his lips.

"I thought the boy would be taking one of his long walks, under a full moon, and the hubcap would turn up for him. There'd be rainwater in it, and it would shine in the light. Both of them would."

"What'd he do then? Set fire to some tire rubber and fry frog legs in it?"

"No, but there was a bullfrog. It jumped up and took a bluebird when I 
crossed the creek; saw it in the headlights. One was green, the other was blue. Like a bedspread in a Holiday Inn.

"You know, for a everyday sort of woman, you sure do dream awful things; you ought to resent them."

"I'm not the only one. Those women at church do the same. We used to always talk about them whenever we got to ourselves, after services and lessons. By the way, they found orange peelings and a white tuxedo hanging up in the steeple. It was tied to the bellrope. Everybody knew who it was. The jacket was full of peelings."

"Yea, that's the reason I got this family out of that church. Gossip was all the bunch was good for. We go to a fine church now. The children get exposed to good scripture."

"You're right, honey. I miss some of the company, though. I miss the fish fry."

"So, go on; what happened?"

You mean you're really interested, you care?"

"No, I don't give a damn, but I'm curious."

"Well, you know what they've been having in the news about the stuff on clock hands? What it does to your system. How it is radioactive."

"Phosphorescent paint, you mean?"

"I don't know what it is, but there is some of it on the stations and hours on the clock radio."

"They use it to tell time in the dark, read things at night. Some of it shows up by itself; that's how the clock is. Some of it needs a light on it," he explained to her.

But she was not listening, she only continued her tale of that night, "The green hands that burn in the dark will get you' is what he said."

"Where?"

"In the car. I looked up in the rear view mirror, and there he was-with the crow on his shoulder. It was still the middle of the night. He was eating sardines, holding them up by the tail, throwing back his head like the moon was going to give him a tan; every now and then he would feed one to the bird. I could smell them."

"He's like that; it's what's wrong with him. And if you don't watch out, it'll be what's wrong with you. You ought to be cleaning house, not worrying yourself sick over a nightmare. We can't afford lunatics around this household," he said as he left for work.

"Get some oranges in town, honey," she called to him.

He changed his name every week. He did not like most people calling him by his given, or his last name-the real ones. Only a few were allowed to; only a few of those got a reply if they did. He felt like a Born Stranger. Several times he asked the lady who did the wash to sew the two words on the back of his bluejean jacket in red thread, but she always declined, "We got us enough troubles as it is, child." He was seen-at this mellifluous age-just enough to baffle people as to who he was. The same ones who saw him yesterday, who grinned as he 
walked by, might today ask one another, "Who is he?" Right out of the blue-if ne spoke at all-he might say to the first person he passed, "O, quite to the contrary." Just as most of those his age-with whom he never mixed-prided themselves in some ability on the sports field and with a gun, he, however congenial he could be when wanted, liked to run alone, as they say, the bird trailing after him, or be with Miss Jane when she was sad and mean and drinking. Often, of a morning, he came into her parlor after staying out all night, his canvas duck pants muddy, a sly look on his face, like a gambler. "Well, where have you been all night," was her usual inquiry. He could almost fall asleep standing. "You look like you took the captain's lashing," she said, this time, from the couch, surrounded by her unfinished caning. She was in a sheer gown, holding a green glass with both her hands, inspecting the briar and buckthorn marks on his bare chest. "Turn around," she commanded him. "It looks like the coon hunters have been having their fun with you." There were times the men who went out at night would find him catching mice and toads. He tied them to a curl in the back of his head. The crow would chase the creature in his hair. The boy had more fun than the men did, but they did not know it.

Neither the woman nor the boy cared for himself, or for the world; not even the small part of the world around them. They had a little money. They were different. They were recklessly serene. If something were to happen to one or the other-if either of them were to fall into some physical or psychological sink hole, real or dreamt-it would be one or the other "coming to the rescue" Rescue was the word they spoke most often between them, where others would use love. They ate oranges, wore strange clothes, and listened to "low down music." Some of the women from the nearby church, who had to pass the old home to get to Sunday services, said it was sick. There was one woman who claimed to have seen: "A niggerman smoking a crook, wearing a panama hat, sitting down with $\mathrm{Her}$ at a white, wrought iron table, the two of them playing checkers. If it didn't beat all. The boy was walking across the lawn, buck naked, except for some boots and a frog gig. The niggerman told the boy, holding out his large green glass like never you mind, 'I need a patch on my wing.' He ought to have been cutting the grass." The men at their work were no different from the women at theirs.

The other women did not refer to either of them as crazy, as did the men, only "sick." The boy, for all his extravagance, silence, and tarnation, might be shadowing himself in some pool of light near the window, gazing over his shoulder at a mirror, and she would enter the room, hold out her long arms to him, her eyes in the mirror, saying, "Rescue." She had a slight lisp which made her trilled r's sound like she was saying hush. It was hard for her to say the word rest. The boy would pretend not to hear her, and go on shadowboxing, thinking Chiaroscuro in the eleventh by a TKO. The other women tried and tried not to think about her. And the men were uneasy until his name passed their lips.

Always, it was she who woke him, and the crow awakened her. The bird said 
its piece, then, without hesitation, flew into the bedroom, circled the bed, beating its wings against the light fabric of the canopy.

She slept naked six months out of the year; other times, she wore a flannel gown the color of ash. He wore an odd looking garment, a white caftan with a hood. It was a gift from the man who wore the panama hat and played checkers with Miss Jane. He had gotten it for the boy on one of his voyages around the world. His name was Silvero, and he owned a touring circus. He also had in his name an orchard in Florida and three ancient ships in Sweden. He got onto the boy about not washing enough. More often than not, the caftan was the color of a gunnysack.

After her eyes were open, she raised herself on one arm, took a deep breath through her graceful, aquiline nose, and ran her fingers through the sleeping boy's hair. She meant many things to him he had written in his diary, unknown to anyone but the crow, but she was three things to him, she knew that, even if he was not aware of them. These were the three things she never thought about, the things she liked to think he would not have if it were not for her: freedom, a lover, and a mother.

To have a son, to be a mistress, and to be unconstrained in all things, this was her way of life, for however long she was able to live it. Silvero would be able to help another few years. By then, the boy's music ought to be good enough to let them know.

She got out of the bed, took off her gown, saw to herself in the bathroom. There was a haze from the morning dew on the mirror; it looked bluish-green. She put a wet log on the fire, then took her elbows in hand, and smelled the hickory catch. The warmth of the flames made her drowsy again. She smelled like a piece of bacon, she thought. It was four-thirty, and not many days away from real spring. She held two oranges and felt like a floating caryatid. She got some almonds from the blue bowl on the mantle. A black spider fell down from the still ceiling fan, like a somnambulist's yo-yo.

The crow flew over to the statue and small fountain on the other side of the room. The woman got back in the bed, and he coiled against her. He called her "Miss Jane" or "Lady Jane"; she liked that. She was warm. He was dreaming of her. She was hard at her fine work: caning. He dreamed he was in a basket, floating down the river through the feathergrass. Women were bathing. Moses was one of his favorites. Now he was older and in another country. He was in the cold water of the sea around the snow island where Silvero summered. Silvero was playing the honky-tonk piano, and some Swedish fishermen were standing around, smoking pipes, smelling of fish, and talking like they do. She was the loom to the weaving of thunder. It all made sense to him. She was up to her waist in water, her nipples showed through the wet gown. He was rowing the skiff around her. She was weaving the cane into a swan he would give to the bread woman for a basket. The name of his boat was Lady Jane, but it was she 
who had christened it with her own name. After the swan was finished, he dreamed, she would try to drown it in blue paint, and set it out in the gazebo to rot.

She also had a dream that night, a dream she could no longer completely recall as he could. Taking the knife-which kept his place in a book-from the bedside table, she sliced the orange, and thought about the dream. She was wide awake. Tears of juice dropped into his ear, running down his cheek and neck: The guitar strings have been ripped from the instrument, like a bear might tear out the entrails of a bloodhound. Next, she sees them wound together, like a cable, stretched out between two trees where he often rides. She sees him, in the dream, as he will look in a few years to come. He gallops towards the thin wire. She is in the tree, in riding apparel. Just before he rides into the cord, his head thrown back, she hears the faraway sound of a hunting horn. It is here the crow appears, "Regrets sur quoi l'enfer se fonde," or, at least, she thinks it appears. And she hears cawing. She hears a beating sound. The bird is trapped inside the guitar, fluttering like a black dress left out on the line all night during a storm. A stretch of barbed wire has been strung to the instrument. Shovels of dirt are being thrown into the opening. Now and then she sees the bird's purple eye. The soil is not wet and dark, but more like the dust found at the side of the road. The bird's feathers are covered with it. Even in the dream, she knows it is only a dream.

Although the dream was the same as the night before, she remembered less of it. He was wearing sunglasses and drinking a strawberry soda. He was standing next to a huge willow. Near him, a listing mirror. He was sweating profusely, a yellow bandanna tied around his neck. "I planted the African violet in the guitar, just like you told me," he told her.

$O$ marks the spot, he thought, telling her, "This is where the carnival has come to die." Now, the property is mine, he thought. She went on cutting the cane.

Not thinking about the dreams anymore, she bites into a section of orange, and it sprays her in the eye. Swallowing, she puts her hand under his robe, letting it wander over his body in his sleep. She listens to his breathing quicken. So does hers. The crow drinks water, tossing back its head. She touches him with the orange, and he opens his eye. The caftan is up around his chest, and his nipples are hard as raisins. He looks for the crow, sees it drinking from the mirror. The mirror is huge, and hung several inches off the wall. A few years ago, he could climb up it. It was like coming aboard a ship. The fountain made a wake.

She slips her finger, which smells of orange, under his black patch, as if it were the elastic band to an undergarment. She knows how his eye aches in the morning before it is light. He takes some of the almonds from her hand, and makes juice from the orange, in a half shiver. He rubs his good, damp eye over her nipple, letting his tongue lose its taste of sleep on the salt of her body. It is still not quite light. 
"Would you like eggs?" she asks.

"I would, very much."

"On your way for the bread, you can gather some. I have to look at the give on the laminating. If the weather will only stay clear, the wood will turn out fine."

"What book and what music?" he asks.

"Whatever you like. Something short and pleasantly violent. Something I can read in one sitting. And jazz. You've been too sad the last few months with your music."

"When you are in the mood, I have a long book by a Greek . . Kazan . . ."

"Kazantzakis."

"And what for supper?"

"You say."

"Fresh fish, some peaches, yogurt, and honey. I will catch a fish this afternoon and skin it at dusk. A catfish."

"And if you don't?"

"We will have boiled crawdads. You can peel them; I'll get new butter."

"We don't have yogurt or butter."

"We'll eat. I'll go back to the bread woman's. If I had gone later yesterday, I could have had those things. She doesn't begin her work on them until the schoolbus has come for her children."

"You talk as if you like going there."

"I do."

Just as it was getting to be light, the boy would go out to the veranda, climb up on the railing, and yell. In his dirty robe, he looked like a Muslim saying his prayers. Whenever the others who lived nearby heard him, they knew all was well-at least with them.

For some time it had been raining. "Raining to beat hell." On these mornings, he could not go on the long walks alone, playing the clarinet. He couldn't take his time. He had to wear a yellow raincoat, and run back with the fresh bread and other things as fast as he could. He would rather die than hurry, and since death, they said, was the worst thing of all, it probably came in a hurry. When it was dry and warm, he'd play and suck oranges until he reached the river. He swam and fished every morning, when it was good, alone. He stayed in the water until his lips turned blue, until the water snakes were no longer afraid to hunt frogs. He liked to tread with them. When he came out of the water, the first thing he did was clean the ants from the sweet saliva in his clarinet.

If there was no danger of her hearing him, he played Pete Fountain. He was supposed to practice the other music, but he really liked "Stranger on the Shore." She did not know it, but what he really wanted to do was go to Memphis and play that song in the lobby of the Peabody Hotel, just when everyone was sitting down to their noon meal. He wrote a letter to Silvero in Sweden telling him of his ambitions. Silvero sent him a telegram, in care of the wash lady, "Wait. Stick with me. Don't play all your cards yet. I have connections on Beale. See 
you next season. As always, Mr. Silvero." There was a breeze. He wanted to be in his boat, all the lines baited, the wind rattling his book like a snake, and playing his rendition of the song when the bread lady came down to the river to gather berries. He wanted it to be full daylight with no clouds.

He liked to dream of the places he'd been when he was too young to remember, of the way words sounded when you used them by themselves, of the odor of the bread lady's house; he liked to think of these places, say a word out loud, then put the reed to his lips. He would think of Florida, say "languorous," then play the clarinet. He'd been to France, England, Germany, and Norwaycould remember none of them, and had set music to clever, veto, bizarre, discordant, harsh, aloof, Dr. Pepper, silent, and Yokohoma rooster, but he could only remember vervel and Florida. Mr. Silvero took him alligator hunting there.

He was pulling on a blue sock, getting ready to go on his way to the bread lady's after butter, yogurt, and loaves, when Miss Jane told him she needed the other. It was kind of early, he thought, but she must be out. He really didn't want to ride into town, especially if it rained this early in the day; the men would be there drinking, unable to work. In his mind, he wasn't going; until she played with his ear, saying, "Rescue me." Today was the first morning he thought it sounded silly. He tried to recall how old he was, but he couldn't. He never could. What difference did it make? I can't go to school anyway. He had gone up within a hundred yards of the building once; played the clarinet on the other side of the tracks during recess. Three girls who were skipping rope walked over and spit on him. The teacher ate a candy bar and rang the bell. So he had to ride the horse to town. He saw how beautiful the cane rockers were, how her hair floated up under the ceiling fan. He listened to the wasps outside in the eaves, and looked at her like a man might look at a constellation in the water.

Miss Jane's eyes were like a cameo a drunken stowaway sees a hypnotist swing on a chain made of clover and a lock of hair. For some time he has wondered why bees thrive on flowers and wasps do not. There is a patch of wild flowers in a field off the road near the bread lady's house. He has to pass by her place anyway if he goes to town. He decides to stop in for a visit, not even getting off his horse. All of the other times some business has been transacted. He hopes that the sky will be blue. He feels like water in a fountain just before it descends.

He went by her house, coming through the field. She was not inside. She was asleep at the pump; there was a pan of snap beans in her lap. Beside her, on the green boards of the wooden pump stand, were her husband's straight razor, mug, and brush. He saw the remains of some soapsuds, like the foam swift water makes. She fell asleep working, he thought. He wouldn't bother her. He hadn't come to bother her, only to visit. He did not like the phrase "pay a visit." But he would bother her if he woke her up. He saw the sleeves of her dress were wet. So was the hem. The horse snorted; he whispered to it, "steady." Like a shadow, they came closer to the sleeping bread lady. Her face was not plain at all. He could smell the soap on her skin. She leaned on her arm in such a way that he could see the bare underarm. There were tiny shimmers of down on the sharp blade. He looked at the trickle of blood on her smooth leg. He got down off 
the horse, and snapped the whole pan of beans without a sound, then quietly rode away.

Had he not smelled the bread when he passed her house, it would have burned. It would spoil things if he left a dime, so he took the bread. One of his shoes came off as he backed out the screen door. He dug his heel into the horse and held onto the mane with his teeth. He rode so hard, he felt like he was smothering.

As he galloped on his way to the Dive, he couldn't resist the hot shade of the Mushroom Woods. His horse drank, while he gathered eggs, berries, and mushrooms. A bright snake sunned itself in a weeping willow. He picked it up and put it under a cloth in his basket. Breeds of strange chickens, with beautiful feathers like peacocks, had become wild in this neck of the forest. There were legends of bulldozers and catskinners being sent into the dark part to clear a logging road and they were never heard of again. You had to follow turkey and bobcat crap on rotten logs if you wanted to stay out of the quicksand, they said. There were other legends. And some of them were true.

He came into town very muddy. His lips were burned from the wind. He did not take it upon himself to stop by the Post Office and ask for Miss Jane's mail. (If he had, he would have found a letter from Sweden. It was from a high-wire artist. One night while it was snowing, during a performance by the sea, the tent had caught fire. Most of the animals were lost. Silvero was on his way to Florida with what little money he had left. A few injured performers, a charred carousel, and a zebra were on their way to Miss Jane's place.) Instead, he was caught by the sign on the screen in the store. WONDER BREAD: Helps Build Strong Bodies Twelve Ways. It had been ever so long since he had eaten any store bought bread; he couldn't resist it either. The man watched him swallow every slice, and gave him four glasses of free ice water to help wash it down. He had more than enough to get what Miss Jane wanted, so he bought a small vial of Magnolia Sweet Oil. Outside again, he poured the entire bottle over his head. The horse turned his head, and the crow flew away. His belly sounded tight as a melon when he thumped it. Names for the weeks to come were swimming through his head as he went after Miss Jane's needs: Eclipse, Distant, Zephyr, Bad Blood, Dramatis Personae, Carl, and Valhalla.

The Dive was eighteen miles from where they lived. When he walked in the large, dark room, he was so beautiful, the old timers turned up their bottles, taking a long swallow. All of a sudden, the men developed coughs or specks in their eyes. They didn't seem to like it that he was sold to, right over the counter, in plain view, even though he wasn't nearly of age-and the bartender knew it. They all knew who she was. If they had known who he was, it would not have made any difference.

The man who tended the Dive always asked the same question, "The same?" Ordinarily, he was a man of quite a few words. The boy raised up two fingers of his left hand, letting his eye wander around the room. He set the basket on the counter. He waited for the man to bring Miss Jane's bottles, watched another make sausage, when the snake-what he thought was a kingsnake-crawled 
out on the counter. Most of the men were sniffing. A drunk came over to him and asked what kind of bread it was. The boy told him it was verbena bread, made from the blossoms of the state tree. While he waited for the bottles, a man with a gold tooth broke the snake's neck with the bottom of a heavy glass mug.

"Damn boy. That's a coral snake. Don't you ever pull anything like it again, Delius."

The boy was incensed. Without any call, the man had killed the snake. And, he called him by his real name. He was so angry, I have to think, he thought. So it was a poisonous one; so what. He never could remember the rhyme about the color of the rings and their order. It was like the ditty Silvero sings about wine, whiskey, and beer. He drew blood from his bottom lip.

"You have no call to use my name. If you have to call me something, I'm Smoke. You got it?" Then, to the other man, "Give me the liquor."

"Smoke, is it? If I laid a board across your backside, you'd smoke all right."

The rest of the men in the bar got a kick out of what the man said. Some, still beguiled by the bread, requested the recipe. The boy paid them no mind.

Like a gracious actor, he stepped forward with one leg, bent-kneed, extending his left hand, palm up, "Kind sir, if you lift your hand against Delius, you'll . .."

His horse, the loyal sidekick, stepped into the bar. It was very dark as it moved out of the light.

The man gave the high sign for a lunatic. The boy looked him in the eyes, like a man looking in a mirror, practicing for a duel at sunrise.

"Get the animal off the premises," the bartender yelled.

Bottles full of liquid make a strange sound when they come together. He put them in the basket, and walked towards the horse. Everyone kept their eyes on him, careful he did not reach into his saddlebags. "We are leaving."

When he rode off, he was so full of silent rage, he took the wrong way out of town. The others looked through the windows of the Dive. The clouds went by without any danger of rain. The sun was like a fish with a crawdad in its mouth. The boy saw a flat rock. No, it was a piece of concrete-broken off from the new sidewalk the Town Council had just put down. He stepped down. For a moment, he intended to pick it up and throw it through the front window of the Dive, but the crow, roosting on the blade of a broken-down bulldozer, swooped down, taking the long night crawler from the moist place in the ground the boy had just uncovered. He thought about passing water on the flat chunk of concrete, but he decided to wait until he got back out of town, where the butterflies would light around it. At the end of the street, he looked up and saw the barber sitting down in his place, reading a magazine. He knew, then, he was heading the wrong way.

He turned the horse around, and went back in the other direction. Some of the sidewalk, he noticed, was dark green instead of gray. He saw it was new, soft like mud. He wanted to walk through it. When he looked closer, he saw something else already had. The crow.

All but one of the same ones were still standing there, near the window, as 
he rode past. He did not look at them, but the bird threw them a glance. He took his clarinet from the saddlebags, and the men jumped back from the glass. He played one of the pieces he was working on, the one Miss Jane told him to practice. She's found it by now, he thought, hoping the bread lady would have found the page he tore from the book in his saddlebag. He tied it on the end of the pump handle with monofilament line. Whenever she woke up, she would see it, hovering like a kite. He hoped she would be resting in her house when he got there. The crow would fly in and open the latch on the screen. He would sit down in the kitchen, listen to the ants and her breathing in the next room, and play. If it turned hot in the afternoon, he might even turn on the fan, and watch it go around as it went back and forth stirring up the dust on the floor.

The man with the gold tooth looked down on the black counter. There was a mushroom and a trace of snake blood. He looked at himself in the last sip in his glass mug. He tilted it, seeing through the end of it. Suddenly, the very thought of drinking the beer made him sick to his stomach. He felt dizzy; his stool seemed to sway. He thought of the boy and he smelled toads. The place seemed quiet for a minute, as if the others were waiting for him to fall.

The bread woman read what the boy had torn out: "Celui qui est entré dans les propriéés de l'âge, il n'en cherchera plus les pavillons ni les jardins, ni les livres, ni les canaux, ni les feuillages, ni la trace, aux miroirs, d'une plus brève et tendre main: l'oeil de l'homme, en ce lieu de sa vie, est voilé . . ." Of course, she could not understand a word of it.

He heard the boy go by on horseback, playing the clarinet. He thought a man in the back near the pool tables said, "Rack!" He vomited on himself. It went down his leg into his boot. That night, he would dream he plucked a berry from the socket under the boy's black patch. 